\title{
Trade Shocks and Firms Hiring Decisions:
}

Citation for published version (APA):

He, C., Mau, K., \& Xu, M. (2021). Trade Shocks and Firms Hiring Decisions: Evidence from Vacancy Postings of Chinese Firms in the Trade War. Labour Economics, 71, [102021]. https://doi.org/10.1016/j.labeco.2021.102021

Document status and date:

Published: 01/08/2021

DOI:

10.1016/j.labeco.2021.102021

Document Version:

Publisher's PDF, also known as Version of record

Document license:

Taverne

Please check the document version of this publication:

- A submitted manuscript is the version of the article upon submission and before peer-review. There can be important differences between the submitted version and the official published version of record.

People interested in the research are advised to contact the author for the final version of the publication, or visit the DOI to the publisher's website.

- The final author version and the galley proof are versions of the publication after peer review.

- The final published version features the final layout of the paper including the volume, issue and page numbers.

Link to publication

\footnotetext{
General rights rights.

- You may freely distribute the URL identifying the publication in the public portal. please follow below link for the End User Agreement:

www.umlib.nl/taverne-license

Take down policy

If you believe that this document breaches copyright please contact us at:

repository@maastrichtuniversity.nl

providing details and we will investigate your claim.
}

Copyright and moral rights for the publications made accessible in the public portal are retained by the authors and/or other copyright owners and it is a condition of accessing publications that users recognise and abide by the legal requirements associated with these

- Users may download and print one copy of any publication from the public portal for the purpose of private study or research.

- You may not further distribute the material or use it for any profit-making activity or commercial gain

If the publication is distributed under the terms of Article $25 \mathrm{fa}$ of the Dutch Copyright Act, indicated by the "Taverne" license above, 


\title{
Trade Shocks and Firms Hiring Decisions: Evidence from Vacancy Postings of Chinese Firms in the Trade War
}

\author{
Chuan $\mathrm{He}^{\mathrm{a}, *}$, Karsten Mau ${ }^{\mathrm{b}}$, Mingzhi Xu ${ }^{\mathrm{c}}$ \\ ${ }^{a}$ Huazhong University of Science and Technology, School of Economics (SOE), China \\ ${ }^{\mathrm{b}}$ Maastricht University, School of Business and Economics (SBE), Netherlands \\ ${ }^{\mathrm{c}}$ Peking University, Institute of New Structural Economics (INSE), China
}

\section{A R T I C L E I N F O}

\section{JEL classification:}

D22

F13

F14

J23

\section{Keywords:}

Trade war

Tariffs

Online job vacancies

Firm recruitment

\begin{abstract}
A B S T R A C T
This paper studies adjustments in labor demand of firms exposed to the recent China-US trade war. Our analysis leverages information from a Chinese online job board and a firm-level measure of tariff exposure obtained from customs transactions data. Firms that are more exposed to US tariffs on Chinese goods responded by posting fewer job vacancies and offering lower wages. The latter is partly balanced out by increased non-wage compensation. We also find a negative relationship between US-tariff exposure and the educational background required in firms' job ads. China's retaliatory tariffs against the US does not appear to have a statistically significant systematic impact on hiring. The paper also reports heterogeneous adjustment patterns across firms of different size, ownership and product mix. Overall, the trade war reveals to have negative impact on firms and job-seekers in China.
\end{abstract}

\section{Introduction}

The recent escalation of the US-China trade war resulted in a substantial disruption of trade between the two countries. US imports from China hit a 5-year low in 2019, ranging about 33bn US dollars below their value from 2015. US exports to China were about 9.5bn dollars below 2015-levels. Comparing shipments in 2016-2017 to the years 20182019, US imports from China decreased by 14-23 percent, while US shipments to China decreased by $15-27$ percent. $^{1}$

Disruptions are not limited to aggregate trade flows. While exposed exporting firms have to cope with an artificial increase in the price of their sold products, importers have to pay more for their purchases or find new suppliers. Both see their competitiveness eroding and lower sales and profits force them to re-optimize their cost structure and investment decisions, including their labor demand.
In this paper, we use newly collected information from online jobvacancy postings in China to document firm-level reactions to the trade war reflected in labor demand. By observing information on the number and content of online job ads between May and November 2019, we capture the most recent round of US tariff increases and Chinese retaliation. This enables us to evaluate responses to the trade war at an early stage of firms' hiring process along several dimensions. Our results provide novel insights into the propagation of short-term responses by firms to adverse trade policy shocks.

An important feature of the trade war is that the introduction of new tariffs did not follow a rule-based rationale in the context of conventional WTO anti-dumping or safeguarding regulations. In fact, the US administration first based tariffs on national security interests, but later raised tariffs on goods even if they were not currently imported from China (Bown and Kolb, 2019; Handley et al., 2020a). This lends support to a key identifying assumption: that Chinese firms had no influ-

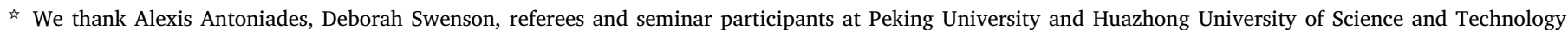

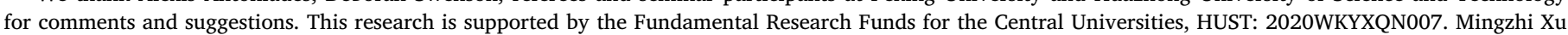

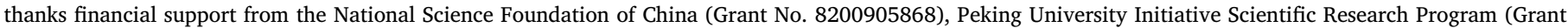
No. 7101302576) and Peking University International Strategic Cooperation Research Program (Grant No. 7101702318).

* Corresponding author.:

E-mail address: chhe@hust.edu.cn (C. He).

${ }^{1}$ Calculations use monthly trade statistics reported by the US International Trade Commission (USITC), where trade values are reported in current prices and

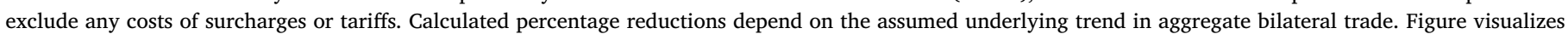
these numbers.
} 
ence on the timing, magnitude and coverage of the tariffs. ${ }^{2}$ Moreover, magnitude and product coverage of the additional (discriminatory) tariffs have been unseen for decades, which enables us to study a policy experiment that is unique in contemporary economic history.

Indeed, the theoretical linkages between tariffs and firms' labor demand can be manifold and predicted outcomes are potentially ambiguous. Some intuition can be derived from trade models with heterogeneous firms and imperfect product-market competition (Melitz, 2003; Melitz and Ottaviano, 2008; Melitz and Trefler, 2012). Depending on modeling assumptions and initial product-market conditions, tariffs are either fully or partly passed through to customers, while lower profits follow in both cases. With (partial) pass-through and downward-sloping demand, exporters face lower sales, downscale their production, and might eventually demand less labor. Moreover, (partial) absorption of a tariff-induced price increase might result in lower salary offers by firms, as they seek to preserve market access (and restore profit margins) through lowering their factor costs. ${ }^{3}$

Adjustments by firms facing new tariffs on their imports after Chinese retaliation are more difficult to predict. On the one hand, firms sourcing intermediate inputs from the US might switch to alternative (second best) suppliers, which potentially undermines their competitiveness vis-à-vis less exposed firms (e.g., Handley et al., 2020b). Fewer job postings could reflect an ensuing decline in labor demand. On the other hand, instead of switching suppliers, exposed firms could manufacture the tariffed inputs themselves and hire additional workers. ${ }^{4}$ This is reminiscent of the rationale proclaimed by the US administration when it imposed additional tariffs on Chinese goods: higher tariffs might boost domestic production and employment through import substitution.

At least two elements complicate such reasoning. First, the US-China trade war has created substantial economic uncertainty among Chinese firms (Benguria et al., 2020). While selection, timing, and magnitude of additional tariffs did not follow any rule-based mechanism, also their duration is unknown. Second, job vacancy postings signal firms' willingness to invest now into their future workforce. With the future being uncertain, such investments might be delayed, so that a positive employment effect becomes less likely to materialize in the short run (Bloom et al., 2007; Ghosal and Ye, 2015; Stein and Stone, 2013). Further complicating elements relate to the characteristics of the Chinese labor market itself. Depending on the intensity at which firms compete for qualified staff, there might be more or less room for adjustments in published salary offers. Similarly, formal and informal labor market institutions that determine the costs of hiring, firing and delayed hiring might influence firms' adjustments.

Against this background, we present reduced-form evidence on the effects of tariffs on firms' labor demand, as reflected by their publicly posted hiring announcements via a major Chinese job-portal. A main advantage of using online job advertisements is their rich information that is typically not observable in firm-level census or survey data. This includes, for instance, the number of open positions and their change over

\footnotetext{
2 This does not rule out that Chinese firms may have anticipated a trade war and specialized away from any trade with the US. We discuss potential implications of this and other identification issues in the main body and in the conclusions of our paper.

${ }^{3}$ A recent article in The Wall Street Journal (WSJ, 2020) reports that Chinese toy manufacturers respond to additional US tariffs by using cheaper (and lower quality) inputs. Similar cost-saving adjustments could occur via offered wages. More systematic evidence from Cavallo et al. (2019) suggests that additional US tariffs faced by (Chinese) exporters are almost entirely passed through, while importing retailers partly absorb them at the expense of lower margins. In turn, US exporters facing retaliatory tariffs tend to lower their prices.

${ }^{4}$ Hummels et al. (2018) identify such "make-or-buy decisions" as one key element of offshoring (or re-shoring in the present case), which depends on the relative costs of sourcing. An ad-hoc switch to in-house production might also be realistic for firms that already produce certain varieties of their imported goods (Bernard et al., 2020).
}

time, as well as the average wage offered for a particular job. Besides this, we are able to observe different forms of non-wage compensation (such as bonuses, subsidies and insurance packages) as well as specifications of job prerequisites (e.g., previous working experience or educational background). Our identification strategy relies on a firm-specific measure of exposure to the trade war, which we construct based on pretrade war information about firms' product mix and trade partners in a matched firm-level customs data set.

Our panel regression results suggest that firms exposed to higher US tariffs responded by posting systematically fewer job ads. The reduction amounts to about 2.4-3.2 percent for an average firm, which adds up to about 5,600 fewer job postings in total. A negative impact is also found for the average wage compensation indicated in the job ads. Our estimated 0.5 percent decrease corresponds to about $\$ 70$ lower earnings per year in an average job offer. Such reductions appear to be balanced out partly by other forms of compensation, such as bonuses. This might suggest that firms shift towards more flexible and performance-based compensation schemes as they face higher US tariffs. Moreover, we find a robust and negative relationship between US-tariff exposure and the required educational background, while requirements on previous job experience do not show any statistically significant response. The reduction in educational-background requirements might reflect that US tariffs disproportionately targeted relatively skill-intensive products. ${ }^{5}$

In contrast to these findings, we do not detect any comparable systematic adjustments to China's retaliatory tariffs on US products. While the sign of the corresponding coefficient tends to be the opposite of that for US tariffs, their magnitude and precision are substantially lower. This is similar to findings of related studies in the US, where import tariffs fail to create new jobs or boost manufacturing sector performance (e.g. Flaaen and Pierce, 2020; Goswami, 2020). In fact, any notable producer gains seem to be either offset by costlier imported inputs, or by the recent (and potentially temporary) nature of these tariffs that prevents firms from investing into new jobs quickly. ${ }^{6}$ Our main findings are maintained after submitting our results to a number of robustness checks, although we document some differential responses across firms of different size, ownership, or product mix.

Overall, the US-China trade war appears to hurt both firms and jobseekers, creating losers on both sides. This conclusion is in line and complementary to existing studies on the trade war, which focus primarily on the US economy (Amiti et al., 2020; 2019; Fajgelbaum et al., 2020; Flaaen and Pierce, 2020; Goswami, 2020; Handley et al., 2020a; Waugh, 2019) or on trade and investment effects in third countries (Egger and Zhu, 2019; Meinen et al., 2019). We add to this literature by shedding light on the experience of Chinese importers and exporters during this episode of political escalation.

Our reduced-form evidence provides novel insights on short-term labor-market effects of the trade war. While existing studies typically rely on more aggregated regional labor market data, we uncover another layer by observing firm-level adjustments in the number and content of vacancy postings over time. Our findings are also similar to Javorcik et al. (2019), who report decreasing online-hiring activity in the UK after the Brexit referendum, due to increased trade policy uncertainty. While their approach relies on differential industry-sector and regional exposure to a major trade-policy shock, we explicitly control for aggregate variation along these dimensions to document more nuanced adjustments within firms. Our findings corroborate evidence on

\footnotetext{
5 This interpretation is in line with Atkin (2016); Blanchard and Olney (2017) and also with the notion that US tariffs disproportionately targeted intermediate inputs (Handley et al., 2020a). A reduction in educational background requirements could also be the result of changing organizational hierarchies in exposed firms (Caliendo et al., 2020): establishments facing a negative demand shock reduce the relative size of their management layer.

6 This is in line with theories on firms' investment behavior under policy uncertainty, considering a significant option value of waiting (e.g. Handley, 2014; Handley and Limão, 2015).
} 
the adverse effects of international political disintegration and uncertainty on economic activity. Finally, by using newly collected data from a Chinese job board, our study also contributes to a growing literature which uses online vacancy postings to analyze and compare labor market dynamics in different countries, as we will discuss in the following section.

The rest of the paper is organized as follows. Section 2 introduces and describes our data in detail, along with the sample used to carry out the analysis of the present paper and its potential limitations. In Section 3, we provide additional background information on key events of the trade war, which are relevant for our identification. Section 4 explains our empirical strategy to identify the impact of tariffs on labor demand. Section 5 presents our results, including robustness checks, explorations of heterogeneous responses across firms, and a short discussion of the implications of our findings. Section 6 concludes.

\section{Online job-vacancy data}

We join a growing literature that uses job vacancy data to understand a variety of issues related to the labor market. Since the early study of Kuhn and Skuterud (2004), several papers exploit such information to study, among others, the relationship between firm performance and skill demand (Deming and Kahn, 2018; Kahn and Hershbein, 2018), firm's financial health and its recruiting outcomes (Brown and Matsa, 2016), as well as other demand-side features, such as gender discrimination (Kuhn and Shen, 2013), search effort and search duration (Faberman and Kudlyak, 2016), or labor market concentration for specific types of jobs (Azar et al., 2018). While most job-vacancy datasets stem from English job-ad platforms, ${ }^{7}$ Kuhn and Shen (2013) are an exception, using vacancy data from the Chinese recruitment website Zhaopin.com from the years 2008-10. Our data is similar to theirs, but has broader coverage and overall greater resemblance with China's cross-regional and sectoral employment patterns reported in administrative data, as we outline below.

\subsection{Data source and collection}

Our data comes from Qian Cheng Wu You 51job.com (hereafter, 51 job.com), a leading company for recruiting and human resource services in China. According to its recent annual reports, the platform mainly targets (early career) white-collar workers in a wide range of job categories. Since the launch of the platform in 1999, the company counts about 150 million registered job-seekers and estimates that, today, almost 500,000 unique employers use their online recruiting services every year. ${ }^{8}$

We are interested in the publicly available information provided to job-seekers via online vacancy postings at 51 job.com, which comes in a standardized format as shown in Figure (a). Information states offered salary and non-wage compensation, job requirements regarding educational background, working experience, language and computer skills, a detailed job description with keywords, and the working location. Because job ads are linked to a firm's page, we also have basic information on the firm characteristics, such as ownership, scale of employment, and main industry. This information allows us to investigate labor demand along several dimensions while controlling for factors reflecting

\footnotetext{
7 Examples are Craiglist (Kuhn and Skuterud, 2004), the Job Openings and Labor Market Turnover (JOLTS) survey from the BLS (Davis et al., 2012; 2013), Burning Glass (Deming and Kahn, 2018; Javorcik et al., 2019; Kahn and Hershbein, 2018), indeed.com (Mamertino and Sinclair, 2016; Turrell et al., 2019), CareerBuilder.com (Brown and Matsa, 2016; Marinescu, 2017), and Snagajob.com (Faberman and Kudlyak, 2016).

${ }^{8}$ Numbers presented for the years 20162018 range between 460,000 and 520,000 (see https://ir.51job.com/ir/doc/2019/2018Form20FEDGARFINAL20190329.pdf, page 28).
}

unobserved characteristics of a location, industry, or firm. Via a unique URL-based vacancy-identifier (see panel (b) of Figure ), we can track job posting activity of firms over time.

We collected information systematically since May 2019 to construct a dataset with monthly frequency covering the period through November 2019. To obtain an as complete as possible record of job-postings, we collected information several times per month and deleted duplicates thereafter to avoid double-counting. ${ }^{9}$ This procedure resulted in 1.7-2.7 million distinct job vacancies per month, from 297 prefecture cities in 31 Chinese provinces. ${ }^{10}$ We can further distinguish about 60 different industry sectors. Since tariffs are applied only on imports of physical products, we will mainly focus on job postings from a subset of these industries and neglect potential indirect effects through upstream or downstream propagation of the tariff shock. Overall, both manufacturing and non-manufacturing industries reveal a similar downward trend in their number of job postings towards the end of the year (see Figure ).

Caveats. To reflect on our collection procedure, we emphasize an important issue that potentially challenges an accurate representation of labor demand in online job-vacancy data. As discussed in related research, ${ }^{11}$ recruiters are inclined to keep expired or old job ads to signal greater supply and choices to job seekers. Cheron and Decreuse (2017) find this issue of "phantom vacancies" to be substantial. Unfortunately, our data does not allow us to detect such distortions, so that the actually reported number of job ads might overstate the true number of active job postings. Consequently, variables constructed from such data will be more rigid. With respect to purposes of our study, identifying the impact of tariffs on firms' vacancy postings, this will likely result in quantitatively lower and less precisely estimated coefficients. The same implications apply to estimated changes in the content of observed job ads, assuming that inactive job ads are no longer updated and therefore suppress variation in the sample. With this limitation in mind, the following subsections present detailed descriptive statistics of our data and sample used.

\subsection{Representativeness of the data}

In Figure 1 we illustrate the geographic coverage of our data on a map indicating the city-level administrative division. The relatively few and sometimes missing observations appear mostly in China's sparsely populated regions, while most of the revealed hiring activity takes place in Central and Eastern China. Indeed, the average incidence rate of unique job vacancy postings per month is highly correlated with citylevel employment and GDP figures, as we show in Appendix Figure.

Despite broad geographic coverage, online job-vacancy data comes at the expense of potential limitations in their representativeness for the labor market. As discussed in related research, entry- and high-turnover jobs are likely to be over-represented and job ads posted online tend to require a higher educational background than traditional job boards (Davis et al., 2013; Kahn and Hershbein, 2018; Kuhn and Shen, 2013). By targeting young white-collar workers, 51 job.com seems to share such characteristics.

To further examine the features of our data, we compare our sample to national census data that is representative to the realized employment

\footnotetext{
9 See Section in our Data Appendix for details on our collection procedure.

10 We refer to cities as the second layer of administrative division in China. The 31 provinces denote the first layer, which include four centrally-administrated municipalities (Beijing, Chongqing, Shanghai and Tianjin) and five autonomous regions (Guanxi, Inner Mongolia, Ningxia, Xinjiang, and Tibet).

11 See Gregg and Petrongolo (2005) and Ebrahimy and Shimer (2010) for introductions to stock-flow matching models. Cai et al. (2017) and Albrecht et al. (2020) extend the discussion to a variety of meeting technologies and market structures, while Cheron and Decreuse (2017) and Albrecht, Decreuse, Vroman use both theoretical search models and empirical evidence to reveal the existence of frictions resulting from "phantom vacancies".
} 


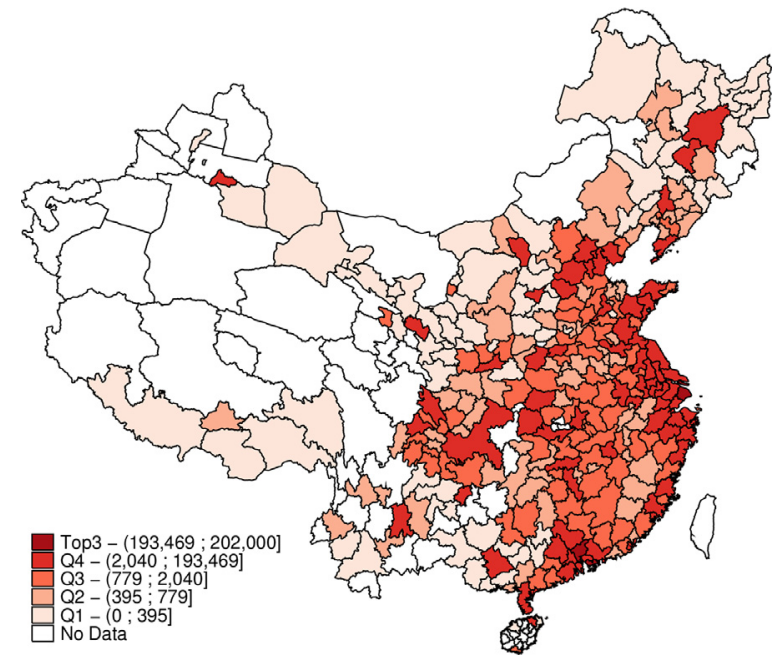

Fig. 1. Geographic coverage and concentration of job vacancies, full sample Note: Authors' calculations based on data downloaded from 51job.com between May and November 2019. Figure shows coverage and concentration of average monthly number of observed vacancies across 297 out of 343 perfecture-level cities. Intervals depict quartiles.

in China. Even though hiring intentions of firms revealed via online jobads differ substantially from realized matches in the labor market, we can still learn from such a side-by-side comparison. Considering the distribution of educational backgrounds in Figure, we observe that more than 70 percent of the advertised jobs require college education as a minimum. While this is less than the 87 percent reported by Kuhn and Shen (2013, Table I), the China Population Census from 2015 and previous editions suggest a much lower shares of 30 percent or less. Differences between skills searched by firms in our data and matched skills in the Census data may explain part of this discrepancy. Nevertheless, vacancies posted at 51 job.com seem to disproportionately target higher skill segments of the labor market.

Regarding coverage and patterns across industries, we compare job postings to sectoral employment and firm populations. ${ }^{12}$ Figure (a) shows the number of jobs across industries, reflecting occupied jobs (i.e. employment) in the Census and job vacancies in our sample. The most salient group - manufacturing - coincides in both data sets, counting 45-50 percent of the jobs. The second and third largest numbers in our vacancy data belong to the health/pharmaceutical sector and to IT services. Neither of them stands out in the census data. Panel (b) of Figure presents the industry distribution of hiring firms. Again, the manufacturing sector dominates in both data sets while energy, health, real estate, and IT services follow in the vacancy data. In contrast to this, the census data prominently features public managements jobs and firms, which is not covered in our data. As in Kuhn and Shen (2013, Table A.1), online job ads appear to be skewed towards the private sector. ${ }^{13}$

\footnotetext{
12 We use the most recent offical census data sets: the China Population Census 2015 and the China Economic Census 2018. More information can be found at National Bureau of Statistics of China. Different levels of sector and industry disaggregation complicate comparison of job-vacancy data with Census statistics and could lead to potential inaccuracies of this assessment. Numerical values should therefore be interpreted in orders of magnitude rather than precise values or cutoffs.

13 See Table for further comparisons of our data to the information from the Zhaopin.com sample used in Kuhn and Shen (2013), and the selected urban census population from China's eight highest-income provinces summarized by the same authors.
}

Table 1

Summary Statistics of Job Vacancies from firms matched to customs data

\begin{tabular}{|c|c|c|}
\hline Panel A. Job vacancy characteristics & Mean & Std.Dev. \\
\hline \multicolumn{3}{|l|}{ Wage offer (10,000 RMB/year) } \\
\hline Average & 10.12 & 16.96 \\
\hline Minimum & 8.01 & 13.08 \\
\hline Maximum & 12.22 & 21.23 \\
\hline \multicolumn{3}{|l|}{ Non-wage compensation (share of vacancies) } \\
\hline Subsidies & 0.56 & 0.50 \\
\hline Bonus & 0.49 & 0.50 \\
\hline Insurance package & 0.71 & 0.45 \\
\hline \multicolumn{3}{|l|}{ Job requirements } \\
\hline Average work experience (years) & 1.76 & 1.99 \\
\hline Minimum & 1.58 & 1.71 \\
\hline Maximum & 1.95 & 2.28 \\
\hline College degree or higher (fraction of jobs) & 0.77 & 0.42 \\
\hline Panel B. Firm characteristics & $\%$ of jobs & $\%$ of firms \\
\hline \multicolumn{3}{|l|}{ Firm ownership } \\
\hline State-owned/controlled & 7.1 & 5.8 \\
\hline Foreign-owned & 21.2 & 28.6 \\
\hline Private-domestic & 71.5 & 65.5 \\
\hline \multicolumn{3}{|l|}{ Firm scale } \\
\hline Small ( $\leq 50$ empl.) & 5.8 & 19.0 \\
\hline Medium-small (50-500 empl.) & 39.5 & 53.8 \\
\hline Medium-large (500-5,000 empl.) & 39.6 & 22.8 \\
\hline Large (>5,000 empl.) & 12.8 & 2.9 \\
\hline Number of unique jobs & & 607,532 \\
\hline Number of firms & & 30,123 \\
\hline
\end{tabular}

Note: Author's calculations based on data collected from 51 job.com. Summary statistics for sample of firms matched with China Customs information, May-November 2019. Reported percentages in Panel B might not add up to 100 , because some firms did not report this information.

\subsection{Data sample}

For our empirical analysis, we constrain our sample to firms that are directly involved in international trade, for reasons we explain in greater detail below. We use the company name stated on 51job.com to find matching records in Chinese Customs statistics and obtain a sample of 30,123 firms which posted 607,532 different vacancies during the period from May through November 2019. ${ }^{14}$

Table 1 presents summary statistics of our sample, where the average annual wage offer ranges around 100,000 RMB. This corresponds to about 14,500 US dollars per year, which is above China's average income per capita. ${ }^{15}$ Many of the vacancies offer some form of non-wage compensation, such as subsidies and bonus payments. Over $70 \%$ of the vacancies provide a package of five insurances and housing compensation as additional welfare benefits for employees. ${ }^{16}$ In terms of job requirements, $77 \%$ of the vacancies require a college degree as a minimum, while the bar of working experience is set at 1.76 years on average (i.e., one year and 9 months). Panel B of Table 1 presents firm characteristics. We observe that privately owned domestic firms dominate the sample, followed by foreign-owned (and invested) enterprises and stateowned firms (SOEs). ${ }^{17}$ Distinguishing firm scales indicates that large firms account for more than half of the job postings in our sample, while they represent only about 25 percent of the firms. Overall, medium-sized

\footnotetext{
14 As company names might be spelled differently across data sets, we require a similarity score of at least 75 percent to qualify as a match. On average firms in our final sample score close to 90 percent.

15 GDP per capita for 2018-19 ranged just below 10,000 US dollars, which confirms that vacancies posted at 51 job.com represent relatively better-paying jobs.

${ }^{16}$ Five insurances include unemployment insurance, endowment insurance, medical insurance, work-related injury insurance, and maternity insurance. Detailed descriptions are presented in Table

17 Comparing the respective percentages for jobs and firms further reveals that foreign-owned firms post relatively fewer job ads via this platform on average than Chinese firms.
} 
(a) US Tariffs

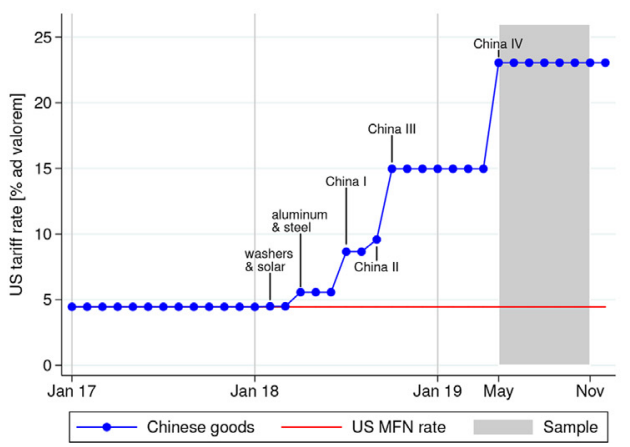

(b) Chinese Tariffs

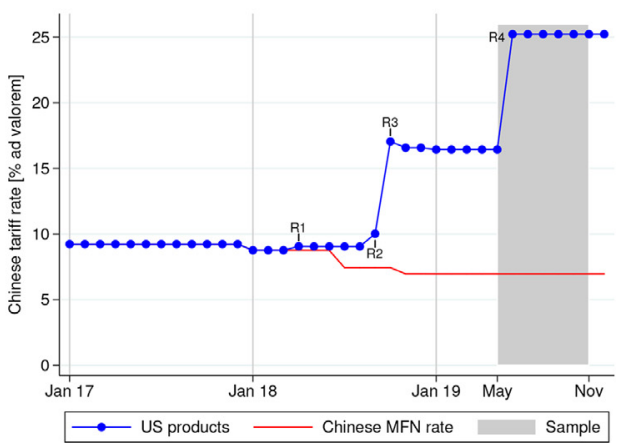

Fig. 2. Average US and Chinese Tariffs Note: Authors' calculations based on data from Fajgelbaum et al. (2020), Li (2018), and own updates. Tariffs denote monthly averages computed from 8-digit Harmonized Tariff Schedules (HTS). Timing determined based on whether effective dates fell into first or second half of a month. R1-R4 indicate rounds of Chinese retaliation. Shaded areas indicate the observations period in our job-vacancy data (Section 2). firms dominate, even though the very large and very small firms also provide meaningful numbers of observations.

We present further summary statistics in Appendix. Figure depicts the geographic coverage of our matched sample, indicating the concentration of job ads as well as average wage levels. Not surprisingly, highpaying job offers concentrate in China's coastal provinces, besides some exceptions. In contrast to the overall sample, the number of vacancies for matched firms appears to be relatively higher the inner-land regions. An explanation could be that modern China has moved its labor-intensive manufacturing base into inner Chinese regions (Mau and $\mathrm{Xu}, 2019$ ), whereas higher-paid jobs are offered in other, more knowledge-intensive sectors outside of our sample. In terms of sectoral coverage, we continue to observe a wide range of industries, but further concentration on manufacturing. Table shows that the top ten industries account for about two thirds of the observed job ads and firms in our sample and contain only one non-manufacturing sector: "Trade / Import and Export". ${ }^{18}$ Monthly summary statistics for the number and key-attributes of the sampled job vacancies are shown in Table. They indicate a gradual decline in jobposting activity over time (including fewer firms posting job ads), but fairly stable compensation offers and job requirements on average. In the following sections we describe how we exploit this data to infer the effects of the trade war on firms' labor demand.

\section{The US-China trade war}

\subsection{Stages of escalation}

Since 2018, the US administration under President Trump implemented protectionist trade policies in several rounds using various justifications. In a first round, in February 2018, global safeguard tariffs were applied on imports of washing machines and solar panels. These were followed by tariffs on steel and aluminum in March 2018, justified with national security concerns. The new tariffs affected major US trading partners, who responded with retaliatory tariffs whenever they saw violations of WTO law (Bown and Kolb, 2019; Fajgelbaum et al., 2020).

Next to these multilateral tariffs, China became a main target of US trade policy following investigations on the abuse of US companies' intellectual property rights and other allegations. Since then, the US government imposed additional tariffs on Chinese products in three rounds in early July, late August and late September 2018. A fourth round followed at the beginning of May 2019, which increased tariffs further on goods that were already targeted in the third round (China III). China retaliated by imposing own tariffs on US products, as shown in Figure 2. The additional bilateral tariffs contrast strongly with the average MFN

\footnotetext{
${ }^{18}$ See Table for a full list of industries.
}

tariffs the two countries apply on imports from most of its trade partners, in line with WTO guidelines. ${ }^{19}$

Tariffs applied also to a broad range of products. The first major rounds of US tariffs on China became effective on July 06th and August 23rd, 2018. They targeted respectively 891 and 244 product categories, specified according to the 8-digit Harmonized Tariff Schedule (HTS), with an additional $25 \%$ increase on the existing rates. China's retaliation to these first rounds targeted an equivalent value of US goods covering 184 and 173 products, respectively, with an extra $25 \%$ rate. ${ }^{20}$ On September 24 th, 2018, the US applied another $15 \%$ tariff rate on 4,626 products valuing about $\$ 200$ billion in imports. China's response entailed a simultaneous tariff increase by 5 and 10 percentage points targeting 4,062 US products worth about $\$ 60$ billion in imports. At the same time, the US administration announced to increase tariffs on the same goods by another 25 percentage points at a later stage and China announced to do the same. In fact, following a meeting in December 2018, the governments agreed to postpone these measures, and China eliminated some of its retaliatory tariffs on US cars and car parts in early 2019. However, another stage of the escalation followed in May 2019, when the US applied the previously announced additional tariffs. China followed a month later.

Despite ongoing threats over the months that followed, no further tariffs had been imposed since then. In December 2019, the two parties announced a so-called "Phase-one Deal" in which China committed to purchase major amounts of US products, while leaving unchanged all other measures taken before. The agreement was signed in mid-January 2020 and came into effect a month later. As our sample with monthly job-vacancy data begins in May 2019, our analysis will focus on the last round of tariff increases, which are denoted by "China IV" and "R4" in Figure 2. At that stage the US had applied additional tariffs on almost 75 percent of the 8,225 products that are defined in the HTS.

\subsection{Potential effects on firms' vacancy postings}

Empirical research on the US-China trade war documents an abrupt and major impact of the tariffs on export revenues of the two countries (e.g. Fajgelbaum et al., 2020; Meinen et al., 2019). While Chinese exporters can theoretically pass on the tariffs to their US customers, it might be rational to absorb (at least some of) the burden to avoid excessive reductions in sales. To absorb the tariff burden, firms have to lower their "factory gate" prices, which can be achieved by lowering mark-ups or unit production costs. Regardless of which strategy a firm adopts, employees are likely to suffer. Lower sales translate into lower

\footnotetext{
19 We do not exploit MFN tariffs in our empirical analysis, but display this information for illustrative purposes and assume that the majority of trade flows are subject to those (stable and predictable) rates.

${ }^{20}$ Earlier, in April 2018, China had imposed tariffs on 87 products amounting to $\$ 2.4$ billion in imports from the US, responding to the steel and aluminum tariffs it had imposed on several of its trade partners.
} 
labor demand. Charging a lower price per unit sold might exert pressure on wages.

While our data does not allow us to trace adjustments for firms' existing employees, we do observe requested characteristics of firms' potential future employees. Given lower sales and the economic and political uncertainty surrounding the trade war, we expect that the number of job vacancies posted by firms facing additional US tariffs will decline (Benguria et al., 2020; Handley, 2014; Handley and Limão, 2015). We might also expect adjustments in the advertised compensation, if local labor market conditions allow for it. However, if wage offers decrease too much firms risk deterring good candidates. Reductions in the offered wage compensation may therefore require an increase in alternative forms of compensation, such as bonuses, subsidies or insurances.

Predicting adjustments in skill-requirements, such as education and previous work experience is more difficult. Skill demand might depend on firms' efforts of shifting sales towards products that are less exposed to US tariffs (Atkin, 2016; Blanchard and Olney, 2017). If such a strategy is relevant, we might observe relatively lower skill-requirements (e.g. educational background) in our job ads, as products shipped to the US belong to the most skill-intensive goods in China's exports (see Figure and). An alternative channel could be that exposed firms respond to lower sales and cost pressure by seeking workers willing to accept lower wages. This might lead firms to request lower minimum standards in work experience and educational background in their job vacancies.

Since the trade-war involved reciprocally applied tariffs, Chinese firms might also be affected by the retaliation of their own government. These might theoretically protect some firms from external US competition, but it is questionable that this gives sufficient incentives for adjustments in labor demand and compensation offers. Given their ad-hoc nature, firms risk being exposed to a sudden removal of these tariffs, which would leave them with too many employees and potential separation costs adding to their earlier hiring costs. Indeed, related studies on the US labor market adjustments fail to provide any evidence of increased hiring and employment in protected industries and regions during this episode (Flaaen and Pierce, 2020; Goswami, 2020; Waugh, 2019).

Finally, since the goods China imports from the US might be important intermediate inputs, retaliatory tariffs might actually hurt importing firms or retailers as their supply-chains are disrupted. ${ }^{21}$ Again, it is unclear how firms would respond: producing in-house and hire more; substitute import source and stay as before; or scale down and hire less. Derived adjustments in labor demand appear to depend critically on specific assumptions, so we intend to answer these questions empirically but remain skeptical regarding major increases in labor demand after Chinese retaliation.

\section{Empirical framework}

\subsection{Firm-level exposure to the trade war}

\subsubsection{Measurement and identification}

We construct two measures of firm-level exposure to additional tariffs and discuss their interpretation. The first measure captures exposure to US tariffs, which mainly affects exporters. The second measure captures exposure to China's retaliatory tariffs on US products and mainly affects importers.

We denote Tariff ${ }_{f}^{\mathrm{US}}$ as the US-tariff exposure of firm $f$, which is constructed as follows:

$\operatorname{Tariff}_{f t}^{\mathrm{US}}=\sum_{j \in J_{f}^{e}}\left[\frac{X_{f j 0}^{\mathrm{US}}}{\sum_{i} X_{f j 0}^{i}} \tau_{j t}^{\mathrm{US}}\right]$,

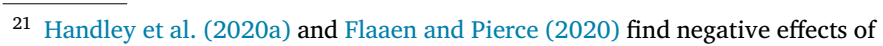
such supply-chain disruptions on US firm and export performance. where $\tau_{j t}^{\mathrm{US}}$ is good $j$ 's ad valorem tariff imposed by the US at time (i.e. month) $t, X_{f j 0}^{\mathrm{US}}$ is firm $f$ 's exports of good $j$ to the US in a pre-sample base-period $t=0$ (i.e. 2016), which we divide by firms' total export revenues from good $j$, as indicated in the denominator. $J_{f}^{e}$ is the set of goods exported by firm $f$. By interacting the US tariff rate with a measure of the relative importance of the US market for each exporter, we obtain our measure of exposure as a weighted average of the US tariff rate faced by firm $f$.

Likewise, based on China's retaliation tariffs on US goods and firms' imports data, we construct our measure of firm $f$ 's exposure to import tariffs:

$\operatorname{Tariff}_{f t}^{\mathrm{CHN}}=\sum_{j \in J_{f}^{m}}\left[\frac{M_{f j 0}^{\mathrm{US}}}{\sum_{i} \boldsymbol{M}_{f j 0}^{i}} \tau_{j t}^{\mathrm{CHN}}\right]$,

where $\tau_{j t}^{\mathrm{CHN}}$ is good $j$ 's ad valorem tariff imposed by China on the US goods at time $t$ (i.e. month), $M_{f j 0}^{\mathrm{US}}$ is firm $f$ 's average imports of good $j$ from the US in a pre-sample base-period $t=0$ (i.e. 2016), which we divide by firms' total imports of good $j$, as indicated in the denominator. $J_{f}^{m}$ is the set of goods imported by firm $f$. By interacting the Chinese tariff rate on US products with a measure of their relative importance for each importer, we obtain our firm-level measure of exposure to import tariffs.

Since we observe both applied tariffs and firms' relative "specialization" in US trade relations in our data, we obtain a fairly direct measure of exposure to the trade war, which is methodologically comparable to related research on this topic (e.g. Goswami, 2020; Waugh, 2019). Furthermore, by employing customs data from 2016 to construct our preperiod weights, we attempt to address endogeneity concerns that could potentially bias our estimates. ${ }^{22}$ However, we also face one caveat for identification, as our pre-sample period weight does not take into account firms' domestic sales and purchases. As a result, it is possible that a firm with a high degree of specialization in US trade relations, according to our measure, is actually specialized in domestic transactions. We would overstate the degree of such a firms' exposure and may likewise understate the exposure of highly export-oriented firms. Although we cannot rule out such a possibility, we expect that such measurement error would lead to an attenuation bias and loss of precision in our point estimates.

\subsubsection{Tariff and trade data}

To construct our measures of firm-level exposure, we combine information from two datasets. The first is the China Customs dataset, in which we observe export and import values at the product-firmdestination (or source) country level for all international transactions in 2016. We use this information to compute the firm-specific weights that capture their relative reliance on US trade relations. We combine this data with a detailed dataset of US tariffs imposed upon China, as well as Chinese retaliatory tariffs on the US, which is reported at a monthly frequency for the years 2016-2019. We collected the reciprocal Chinese and

\footnotetext{
22 Our base year pre-dates Donald Trump's presidency. Although he threatened to impose trade policy measures against China already during his electoral campaign, he was not expected to win the presidency in late 2016. We argue that it is unlikely that Chinese firms anticipated such tariffs, which could affect our measure of exposure (see (Amiti et al., 2019) for further discussion on this issue). Trade statistics from UN Comtrade support this assumption, suggesting that the US share in Chinese exports increased in the years 2016-2018, from 18.4 to 19.2 , before dropping to 16.8 in 2019. The US share in Chinese imports ranged at 8.4-8.5 percent in 2016 and 2017, before decreasing to 7.3 and 6.0 percent in the following two years. Very similar patterns - except for the contractions in 2019 - are observed for China's trade with Germany, another large high-income market, which suggests that any pre-trends observed in China's trade with the US might not be exclusive to their bilateral relations or indicated anticipation of a trade war. Besides this, we also note that any major anticipation effects in firms' hiring behavior would induce a downward bias on our estimated coefficients.
} 
US tariffs from several data sources, including official communications by the US Trade Representative, the CARD Trade War Tariffs Database (Li, 2018), as well as data provided by Fajgelbaum et al. (2020) and Bown and Kolb (2019). US and Chinese MFN tariff rates were collected from the WTO (World Trade Organization) Tariff Download Facility database. Chinese MFN tariffs were further complemented with data from Bown and Kolb (2019), which includes more recent changes in tariffs based on official government communications.

The evolution of these tariffs has already been discussed in Section 3, Figure 2, and we provide further details for the period 2018-2019 in Table. Columns (1)-(4) show that, starting with MFN tariff rates of $3.6 \%$ and $9.2 \%$ in an average (6-digit HS) product category, both the US and China increased their reciprocally bilateral discriminatory tariffs up to $23.2 \%$ and $25.1 \%$ respectively in just two years. Columns (5)-(8) indicate increases in very similar orders of magnitude for our firm-level measure of tariff exposure obtained from Equations (1) and (2). The period since May 2019 is of central interest for our study, where we observe an average increase in firm-level US tariff exposure by about 7.8 percentage points (i.e., from 0.169 to 0.247 in column (5)). Firm-level exposure to retaliatory tariffs increased by about 7.0 percentage points (i.e., from 0.136 to 0.206 in column (7)).

\subsection{Estimation}

\subsubsection{Empirical baseline specification}

To investigate the effect of tariffs on firms' recruiting behavior, we adopt a simple linear panel regression model:

$y_{f t}=\beta_{1} \ln \left(1+\right.$ Tariff $\left._{f, t-1}^{\mathrm{US}}\right)+\beta_{2} \ln \left(1+\right.$ Tariff $\left._{f, t-1}^{\mathrm{CHN}}\right)+\mathbb{X}_{c t}^{\prime} \gamma+\eta_{f}+\eta_{t}+\varepsilon_{f t}(3)$

where Tariff $\mathrm{US}_{f, t-1}^{\mathrm{S}}$ and Tariff ${ }_{f, t-1}^{\mathrm{CHN}}$ are US and Chinese tariffs faced by firm $f$, lagged by one month. We employ lagged tariff exposure since we count vacancies as monthly totals, while actual implementation and responses could have taken place on different dates during the same month. By using lags, we avoid potential problems arising from a different order of events and also allow firms a limited amount of time to adjust to the tariffs. ${ }^{23}$ In line with the empirical trade literature we employ tariff exposure as an iceberg trade-cost term by adding one to the tariff rate and taking logs (e.g., a 5 percent of firm tariff exposure measure would enter the equation as $\ln (1.05)$ ). Overall, the estimated coefficients $\beta_{1}$ and $\beta_{2}$ will indicate the average treatment effect of the final round in the US-China trade war that reveals throughout our 5 months of observations.

To isolate the effect as good as possible, we control for potentially confounding factors and implement firm fixed effects $\left(\eta_{f}\right)$ and time fixed effects $\left(\eta_{t}\right)$ into our baseline estimation equation. Time fixed effects control for aggregate trends or shocks that are correlated with both our dependent variable and our main variables of interest. This includes, for example, seasonal fluctuations in hiring which might happen to coincide with tariff changes. Firm fixed effects are included to control for unobservable time-invariant characteristics of a firm. This is of particular importance in our context, as we do not observe many firm-level characteristics, including its hiring history. However, as we can observe firms' location (at the city level $c$ ), we employ time-varying control variables along these dimensions in vector $\mathbb{X}_{c t}$ to capture aggregate developments in local labor markets. Specifically, we include the total number of firms posting job vacancies as well as the total number of job vacancies available in city $c$ and at time $t{ }^{24}$ Finally, $\varepsilon_{f t}$ denotes an i.i.d.

\footnotetext{
23 Meinen et al. (2019) show that the effects of the trade war on US imports from China started to materialize in the last quarter of 2018, i.e. in the quarter after the first tariffs had come into effect. This is also in line with our descriptive evidence presented in Figure.

${ }^{24}$ Since every firm $f$ resides only in a single location, we suppress city subscripts $c$ in our dependent variable and in the tariff measures to avoid confusion about the dimensions of their variation.
}

error term which we cluster at the city-month level. As an alternative to our baseline specification, we also estimate a model with firm $\left(\eta_{f}\right)$, city-time $\left(\eta_{c t}\right)$, and industry-time $\left(\eta_{j t}\right)$ fixed effects to control for distinct seasonality patterns along those dimensions.

\subsubsection{Dependent variables}

We employ a number of different dependent variables, $y_{f t}$, to analyze alternative outcomes of the US-China trade war. The primary outcome of interest, however, is the number of job vacancies posted by a firm. Such job ads denote the "extensive margin" of firms' labor demand and we consider two ways of measuring it. First, we measure the stock of job ads held by a firm in a particular month. That is, if a firm posts a job in May and it is still online in June and July, it will be counted into our measure of active job postings. A caveat arises when we want to interpret any changes in this variable, due to our inability to observe why a job ad disappears. This can be due to a successful match or due to a withdrawal that resulted from changed hiring decisions. Next to this, such measure faces the "phantom vacancies" issue discussed earlier in the paper, which might keep the vacancy stock artificially high and rigid. We therefore also consider the flow of newly posted vacancies. With this measure, each job ad is counted only once, and a vacancy is considered as being new, whenever it could be observed at download instance $t$ but not at the previous instance $t-1$. A change in this measure might give a clearer indication of the firm's hiring intentions.

Next to counting the number of online job vacancies, we are also interested in the content of the job ads. We analyze these by observing (i) measures of the nominal wage offered in a firms' average job-ad; (ii) indicators of other forms of compensation, such as bonus payments, subsidies or insurances; and (iii) job requirements, as specified by previous work experience and educational background. A detailed overview of the variables along with further descriptions is provided in Table. Since these measures relate to the "intensive margin" of the job ads, we take into account the possibility (and practice) of firms to update their existing vacancies over time. We therefore compute firm-level averages of these variables based on the stock of active vacancies in a particular month.

\subsubsection{Sample structure}

As indicated in Section 2, we analyze the impact of the trade war on labor demand for a subpopulation of firms that are engaged in international trade. The reasons for doing so are threefold. First, many firms in our job-vacancy data might be unaffected by the trade war, simply because they do not engage in international trade (directly or indirectly). Second, even if they are affected indirectly, it is impossible for us to measure their exposure to the trade war, as we do not observe such information. ${ }^{25}$ Third, since typically only a fraction of firms in a country are involved in international transactions, and as such firms are quite distinct from non-trading firms, we do not believe that non-trading firms constitute an appropriate control group. ${ }^{26}$ Instead, our control group comprises an abundant number of firms that trade internationally but not with the US. For those firms Tariff $f_{f t}^{U S}$ and Tariff ${ }_{f t}^{C H N}$ are equal to zero by construction and they count about a third of the firms in our sample. Likewise, we observe about equally-sized groups of firms which are exposed to the trade war through only one channel: either via their

\footnotetext{
${ }^{25}$ Also the reported (more aggregated) industry affiliations cannot be directly translated into firm exposure via input-output linkages as done, for instance, by Flaaen and Pierce (2020). This has implications for the interpretation of our results as we explain in our concluding remarks below.

${ }^{26}$ One reason for this skepticism is differences in firm size that typically prevail between trading and non-trading firms. Another reason is the different market environments in which such firms operate. While trading firms operate at a global scale in highly competitive markets, non-trading firms may be shielded from such competition if they produce and sell exclusively in domestic (niche) markets.
} 
Table 2

Number of vacancy postings and exposure to tariffs

\begin{tabular}{|c|c|c|c|c|c|c|}
\hline \multirow{3}{*}{$\begin{array}{l}\text { Dependent variable: } \\
\text { Number of vacancies }\left(N_{f t}^{v}\right)\end{array}$} & (1) & (2) & (3) & (4) & (5) & (6) \\
\hline & \multicolumn{3}{|c|}{ Stock (all job vacancies) } & \multicolumn{3}{|c|}{ Flow (new job vacancies) } \\
\hline & OLS & OLS & Poisson & OLS & OLS & Poisson \\
\hline $\ln \left(1+\operatorname{Tariff}_{f t-1}^{\mathrm{CHN}}\right)$ & $\begin{array}{l}-3.219 \\
(2.575)\end{array}$ & $\begin{array}{l}-3.247 \\
(2.820)\end{array}$ & $\begin{array}{l}0.270 \\
(0.356)\end{array}$ & $\begin{array}{l}-7.725^{* * *} \\
(2.300)\end{array}$ & $\begin{array}{l}-7.567^{* *} \\
(2.346)\end{array}$ & $\begin{array}{l}0.176 \\
(0.471)\end{array}$ \\
\hline $\ln \left(1+\operatorname{Tariff}_{f t-1}^{\mathrm{US}}\right)$ & $\begin{array}{l}-3.322^{* *} \\
(1.145)\end{array}$ & $\begin{array}{l}-4.200^{* *} \\
(1.582)\end{array}$ & $\begin{array}{l}-0.492^{* *} \\
(0.224)\end{array}$ & $\begin{array}{l}-2.190^{*} \\
(1.112)\end{array}$ & $\begin{array}{l}-6.265^{* * *} \\
(1.348)\end{array}$ & $\begin{array}{l}-0.651^{* *} \\
(0.311)\end{array}$ \\
\hline Observations & 189,272 & 188,909 & 188,705 & 189,196 & 188,880 & 188,479 \\
\hline R-squared & 0.763 & 0.767 & & 0.522 & 0.536 & \\
\hline City Controls & $\mathrm{Y}$ & & & $\mathrm{Y}$ & & \\
\hline Month FE & $\mathrm{Y}$ & & & $\mathrm{Y}$ & & \\
\hline Firm FE & $\mathrm{Y}$ & $\mathrm{Y}$ & $\mathrm{Y}$ & $\mathrm{Y}$ & $\mathrm{Y}$ & $\mathrm{Y}$ \\
\hline City-Month FE & & $\mathrm{Y}$ & $\mathrm{Y}$ & & $\mathrm{Y}$ & $\mathrm{Y}$ \\
\hline Sector-Month FE & & $\mathrm{Y}$ & $\mathrm{Y}$ & & $\mathrm{Y}$ & $\mathrm{Y}$ \\
\hline
\end{tabular}

Notes: Regressions use firm online job vacancy data from May through November 2019. Results in column (1)-(3) are based on the stock of firms' job vacancies, where job ads are counted independently across months. Results in column (4)-(6) are based on flow of new job vacancies, where only the first appearance of each job ID is counted. Time-varying city-level control variables include the total number of firms and vacancies observed. Standard errors are reported in parentheses. For linear models, estimated coefficients denote semi-elasticities and standard errors are adjusted for clustering at the city and month level. For the Poisson fixed-effects models, coefficients reflect estimated elasticities and reported standard errors are bootstrapped. Statistical significance: ${ }^{* * *} p<0.01$, ${ }^{* *} \mathrm{p}<0.05,{ }^{*} \mathrm{p}<0.1$.

exports or via their imports. Overall, about half of the firms in our sample are exposed to the additional tariffs imposed during the most recent round of the trade war, while the remaining firms do trade with the US but were not affected by these tariffs. ${ }^{27}$

Table provides further information on the variation in our sample. It shows summary statistics for average vacancy stocks, wage offers, and firm characteristics by sub-samples of firms with varying lengths of posting job ads. ${ }^{28}$ Not only does the number of firms differ across these sub-samples, characteristics such as the number of vacancies posted, average wage and scale of firms also vary. Both the number of job vacancies and average wages have an upward trend as the duration of job posting increases. Firms with larger numbers of employees are more likely to continuously post job-ads, while small-scale firms post jobs for a shorter duration. This suggests that larger firms also offer better paid jobs on average. Ownership types of firms posting jobs across months are relatively stable across posting lengths. Overall, our data appears to feature sufficient within- and across-firm variation to exploit for the purposes of this study.

\section{Results}

\subsection{Main findings}

\subsubsection{Number of job vacancies}

Our first dependent variable measures the absolute number of job vacancies posted by firm $f$ at time $t$. Since this is a count variable which features zeros and otherwise discrete positive values, we present results for a linear regression approach, as introduced in the previous section, and for a Poisson regression model (Marinescu and Rathelot, 2018; Wooldridge, 2010).

Table 2 displays the results for the stock and flow of firms' job postings, respectively, in columns (1)-(3) and (4)-(6). Throughout all specifications, we find a negative and statistically significant effect of in-

\footnotetext{
27 In our robustness check below, we report results for firms' overall hiring activity based on alternative compositions of our control group.

28 In the first panel, 1-month firms, corresponds to summary statistics for firms that post job ads in only one of the seven months we observe in our sample, while the next panel, 2-month firms, features firms posting jobs for two months, and so on.
}

creasing US tariffs on job postings of exposed firms. Including city- and sector-month fixed effects into our model results in quantitatively larger coefficient estimates, as shown in columns (1)-(2) and (4)-(5). Also the Poisson model suggests that firms that exported to the US reduced hiring efforts when facing increased tariffs. Generally, this effect reveals stronger when we measure the flow of job vacancies, which implies that exposed firms advertise fewer new jobs.

To give these coefficients a quantitative interpretation, we consider the result from column (2) to infer that a one log-point increase in $\ln (1+$ Tariff $_{f t-1}^{U S}$ ) results in 4.2 fewer job vacancies on average per firm. In fact, using numbers from Table, we see that this variable increased by about $0.065 \mathrm{log}$ points during our sample period. This implies about 0.27 fewer jobs offers by an average firm between May and November 2019. As we observe about 20,500 firms at the beginning of our sample, the estimated job loss amounts to approximately 5,600 fewer job postings in total. In relative terms, we observe in Table that an average firm posted about 11.34 job ads at the beginning of our sample period, so that the estimated 0.27 fewer jobs per firm correspond to a reduction by 2.4 percent. Our Poisson results, displayed in column (3), suggest a similar reduction by $(0.492 \times 0.065 \approx) 3.2$ percent.

In contrast to the US tariffs, coefficients estimated for the effect of China's retaliation are less robust. The linear models result in negative coefficient estimates, which are statistically significant only for the new job ads in columns (4) and (5). This would point towards a detrimental effect of Chinese retaliation tariffs on firms' scale of activity, which results in less hiring. However, the Poisson model suggests the opposite when it reports a positive (albeit statistically insignificant) coefficient, which would point towards an increased hiring activity. Overall, the average treatment effect of China's retaliation on firms' hiring activity remains inconclusive.

\subsubsection{Average Wage per Vacancy}

We next study how firms' wage schedules responded to the tariff changes. To do so, we compute for each firm $f$ the average wage $w_{f t}$ offered in the vacancies it had posted at time $t$. Since job ads $(v)$ typically indicate a wage range, i.e. a minimum and a maximum wage (or salary) level, we analyze responses in both of these wages separately and in addition responses in the average of the two $\left(w_{f v t}^{\text {mean }} \equiv\left(w_{f v t}^{\min }+w_{f v t}^{\max }\right) / 2\right)$. In all specifications, we measure wage rates in logs. 
Table 3

Wage offers and exposure to tariffs

\begin{tabular}{|c|c|c|c|c|c|c|c|c|}
\hline Dependent variable & (1) & (2) & (3) & (4) & (5) & (6) & (7) & (8) \\
\hline Wage/salary $\left(\ln w_{f t}\right)$ & Minimum & & Maximum & & Average & & Dispersion & \\
\hline $\ln \left(1+\operatorname{Tariff}_{f t-1}^{\mathrm{CHN}}\right)$ & $\begin{array}{l}0.009 \\
(0.044)\end{array}$ & $\begin{array}{l}-0.002 \\
(0.045)\end{array}$ & $\begin{array}{l}0.035 \\
(0.046)\end{array}$ & $\begin{array}{l}0.022 \\
(0.048)\end{array}$ & $\begin{array}{l}0.026 \\
(0.045)\end{array}$ & $\begin{array}{l}0.014 \\
(0.046)\end{array}$ & $\begin{array}{l}0.026 \\
(0.015)\end{array}$ & $\begin{array}{l}0.025 \\
(0.017)\end{array}$ \\
\hline $\ln \left(1+\operatorname{Tariff}_{f t-1}^{\mathrm{US}}\right)$ & $\begin{array}{l}-0.085^{* *} \\
(0.034)\end{array}$ & $\begin{array}{l}-0.083^{*} \\
(0.042)\end{array}$ & $\begin{array}{l}-0.073^{*} \\
(0.031)\end{array}$ & $\begin{array}{l}-0.065^{*} \\
(0.038)\end{array}$ & $\begin{array}{l}-0.077^{*} \\
(0.032)\end{array}$ & $\begin{array}{l}-0.071^{*} \\
(0.039)\end{array}$ & $\begin{array}{l}0.013 \\
(0.011)\end{array}$ & $\begin{array}{l}0.018 \\
(0.012)\end{array}$ \\
\hline Observations & 107,800 & 107,448 & 107,800 & 107,448 & 107,800 & 107,448 & 107,800 & 107,448 \\
\hline R-squared & 0.738 & 0.742 & 0.732 & 0.736 & 0.734 & 0.738 & 0.736 & 0.740 \\
\hline City Controls & $\mathrm{Y}$ & & $\mathrm{Y}$ & & $\mathrm{Y}$ & & $\mathrm{Y}$ & \\
\hline Month FE & Y & & Y & & Y & & $\mathrm{Y}$ & \\
\hline Firm FE & $\mathrm{Y}$ & Y & Y & Y & Y & $\mathrm{Y}$ & $\mathrm{Y}$ & Y \\
\hline City-Month FE & & Y & & Y & & $\mathrm{Y}$ & & Y \\
\hline Sector-Month FE & & Y & & Y & & $\mathrm{Y}$ & & Y \\
\hline
\end{tabular}

Notes: Regressions use firm online job vacancy data from May through November 2019. Average wages in columns (1) to (6) are measured in logs ( $\ln w_{f t}$ ); wage dispersion in columns (7) and (8) is measured as ( $\ln w_{f t}^{\max }-\ln w_{f t}^{\min }$ ). Coefficients report estimated wage-tariff elasticities. Time-varying city-level control variables include the total number of firms and vacancies observed. Standard errors are reported in parentheses and adjusted for clustering at the city and month level. Statistical significance: ${ }^{* *} \mathrm{p}<0.01,{ }^{* *} \mathrm{p}<0.05,{ }^{*} \mathrm{p}<0.1$.

Table 3 presents our results. We find small positive, yet statistically insignificant, responses to Chinese retaliation tariffs, and negative statistically significant coefficients for the effect of US tariffs on advertised wage levels. Columns (1) and (2) suggest that the lower bound of annual wages offered in our observed job ads decreased among firms that were more exposed to the trade war. The same can be found for the upper bound of annual wages and for the average of the two, in columns (3)(4) and (5)-(6), respectively. Throughout, the estimated coefficients suggest a fairly low elasticity of wages with respect to faced tariffs among Chinese firms. Yet, given the major increase in tariff levels during the trade war, the coefficients imply about $\left((\ln ([1.247])-\ln [1.169]) \times \hat{\beta}_{1}\right) \approx$ 0.5 percent lower wages offered by affected firms (which corresponds to about $\$ 70$ less per year, if the average wage compensation is $\$ 14,500$ as stated in Table 1). ${ }^{29}$ The last two columns confirm that the size of the indicated wage intervals does not change significantly among firms.

\subsubsection{Non-wage compensation}

A lower offered wage does not necessarily imply the labor costs would decrease. Non-wage compensation can account for major portions of total labor costs (Liu et al., 2019; Woodbury, 1983). Indeed, it might be convenient for firms to offer alternative forms of compensation if they have different means to providing such benefits. To evaluate such adjustments, we focus on three different forms of alternative compensation schemes: bonuses, subsidies, and insurances. With bonuses firms can avoid early commitments to paying higher wages when the actual performance of the future employee (but also of the firm as a whole during the trade war) is uncertain. Subsidies include the provision of overtime pay or transportation, communication, and meal allowances by the employer, whereas insurances include the provision of a "fiveinsurances" package that is part of China's social security system. ${ }^{30}$

To evaluate whether firms increasingly advertise the provision of such alternative forms of compensation, we compute the share of a firm's job ads including such components. That is, the share of jobs offering

\footnotetext{
${ }^{29}$ Since job postings quote nominal wages, the income loss in purchasing power adjusted terms is likely to be higher, given overall lower price levels in China compared to high income economies. For example, according to World Bank data, China's PPP-adjusted GDP per capita is about 50 percent higher than the nominal figure.

30 The five insurances include unemployment, pension, medical, work-related injury, and maternity insurances. While being mandatory in principle, it is not implemented throughout the country and some foreign enterprises might be eligible for exemptions from it. See www.china-briefing.com/news/socialinsurance for an overview.
}

bonus payments to employees ( Share $_{f t}^{\text {Bonus) }}$ ) is defined as follows:

Share $_{f t}^{\text {Bonus }}=\frac{\sum_{v \in \Omega_{f t}} \mathbf{1}_{f v t}(\text { the advertisement explicitly offers bonus })}{N_{f t}^{v}}$

where $\Omega_{f t}$ denotes the mass of all vacancies posted by firm $f$ in month $t$, $N_{f t}^{v}$ is the number of job vacancies posted by firm $f$ in month $t$, and $\mathbf{1}_{f v t}$ is an indicator variable that equals to one if job-ad $v$ explicitly mentions that the job will be offered with performance-based bonus payment. We compute shares of jobs offering subsidies, Share ${ }_{f t}^{S u b}$, and insurances, Share ${ }_{f t}^{\text {Ins }}$, in the same fashion.

Table 4 reports our results. Using our baseline specification, we find that firms exposed to higher US tariffs increasingly advertise bonus payments and subsidies as a form of non-wage compensation. This would be in line with earlier conjectures that such payment schemes offer greater flexibility to employers, while providing adequate incentives for qualified candidates to apply (Luft, 1994). However, as we turn to our more demanding specification, including city- and sector-specific time effects, point estimates become smaller and loose statistical significance. About half of the originally estimated effect can be attributed to general industry-level dynamics. ${ }^{31}$ This suggests that sectors where relatively more US-tariff exposed firms operate have been experiencing a general trend in moving towards increased non-wage compensation schemes, and that potential responses due to the trade war are statistically indistinguishable from this trend.

Considering the corresponding coefficients for China's retaliation tariffs, we find similar results in terms of signs, but differences in magnitudes and precision. Coefficients for subsidies, in columns (3) and (4), are quantitatively small and statistically insignificant. The same is true for the share of vacancies offering insurances, where neither US nor Chinese tariffs appear to have affected such policies. In terms of bonus payments, however, we find a robust positive and statistically significant effect of Chinese retaliation in the trade war, which is suggestive of a shift towards performance-based compensation among exposed firms. Although none of our previous indicators revealed a clear systematic response by firms to retaliatory tariffs, the positive signs for wages, vacancy postings (using Poisson estimators) and those presented here (in columns (1) and (2) of Table 4) might be suggestive of a slight increase in labor demand among firms that attempt to substitute imports from the US. Overall, the empirical evidence for an average treatment effect on offering non-wage compensation components is mixed.

\footnotetext{
31 We experimented with different combinations of fixed effects and found that downward correction of point estimates and loss of statistical significance arises from the inclusion of sector-month fixed effects.
} 
Table 4

Non-wage compensation and exposure to tariffs

\begin{tabular}{|c|c|c|c|c|c|c|}
\hline Dependent variable & (1) & (2) & (3) & (4) & (5) & (6) \\
\hline Share of vacancies offering & Bonuses & & Subsidies & & Insurances & \\
\hline $\ln \left(1+\operatorname{Tariff}_{f t-1}^{\mathrm{CHN}}\right)$ & $\begin{array}{l}0.051^{*} \\
(0.026)\end{array}$ & $\begin{array}{l}0.063^{*} \\
(0.027)\end{array}$ & $\begin{array}{l}0.012 \\
(0.044)\end{array}$ & $\begin{array}{l}0.005 \\
(0.046)\end{array}$ & $\begin{array}{l}0.016 \\
(0.026)\end{array}$ & $\begin{array}{l}0.024 \\
(0.025)\end{array}$ \\
\hline $\ln \left(1+\operatorname{Tariff}_{f t-1}^{\mathrm{US}}\right)$ & $\begin{array}{l}0.050^{* *} \\
(0.017)\end{array}$ & $\begin{array}{l}0.025 \\
(0.017)\end{array}$ & $\begin{array}{l}0.046^{* *} \\
(0.017)\end{array}$ & $\begin{array}{l}0.022 \\
(0.014)\end{array}$ & $\begin{array}{l}0.016 \\
(0.020)\end{array}$ & $\begin{array}{l}0.010 \\
(0.020)\end{array}$ \\
\hline Observations & 107,800 & 107,442 & 107,800 & 107,442 & 107,800 & 107,442 \\
\hline R-squared & 0.855 & 0.857 & 0.863 & 0.865 & 0.864 & 0.866 \\
\hline City Control & $\mathrm{Y}$ & & $\mathrm{Y}$ & & $\mathrm{Y}$ & \\
\hline Month FE & Y & & $\mathrm{Y}$ & & $\mathrm{Y}$ & \\
\hline Firm FE & Y & $\mathrm{Y}$ & $\mathrm{Y}$ & $\mathrm{Y}$ & $\mathrm{Y}$ & Y \\
\hline City-Month FE & & $\mathrm{Y}$ & & Y & & $\mathrm{Y}$ \\
\hline Sector-Month FE & & $\mathrm{Y}$ & & Y & & $\mathrm{Y}$ \\
\hline
\end{tabular}

Notes: Regressions use firm online job vacancy data from May through November 2019. Dependent variables denote fractions, coefficients report estimated semi-elasticities. Time-varying citylevel controls include total number of firms and vacancies observed. Standard errors are reported in parentheses and adjusted for clustering at the city and month level. Statistical significance: ${ }^{* * *}$ $\mathrm{p}<0.01,{ }^{* *} \mathrm{p}<0.05,{ }^{*} \mathrm{p}<0.1$.

\subsubsection{Job requirement}

Besides adjustments in offered employee compensation, we are also interested in potentially changing job requirements, which might point towards a shifting scope of activities among exposed firms. Indeed, changes in wages and in the number of posted vacancies could be associated with changes in job requirements. Deming and Kahn (2018), for example, document a positive correlation between average wages offered and the required number of years of schooling. As we found fewer job offers overall, as well as slightly lower wage compensation in our data, we might expect that also the required educational background will be lower.

Like in the previous subsection, we analyze effects on firms' job requirements by measuring the fraction of a firm's vacancies that explicitly require applicants to have a college degree (or higher): of Chinese firms that were directly exposed to higher tariffs. While exporters facing higher US tariffs reveal lower labor demand, wages and skill demand (as well as a tendency to adopt more flexible and non-wage compensation schemes), importing firms' adjustments are less clear-cut.

\subsection{Robustness checks}

In this subsection, we scrutinize the robustness of our findings by addressing potential concerns regarding our identification.

\subsubsection{Placebo experiment with randomly assigned tariff exposures}

For our first robustness check, we perform a placebo experiment in which we randomly assign Chinese and US tariff exposure to firms. The purpose of doing this is to test how likely it is that our baseline find-

$$
\text { Share }_{f t}^{\text {College }}=\frac{\sum_{v \in \Omega_{f t}} \mathbf{1}_{f v t}(\text { the advertisement explicitely require college degree })}{N_{f t}^{v}}
$$

where $\Omega_{f t}$ denotes the mass of all vacancies posted by firm $f$ in month $t, N_{f t}^{v}$ is the number of job vacancies posted by firm $f$ in month $t$ and $\mathbf{1}_{f v t}$ is an indicator variable that equals to one if the advertisement $v$ explicitly mention that the qualified applicants will require a college degree. Next to educational background requirements, firms might also adjust requirements regarding previous work experience (Cai and Stoyanov, 2016). We therefore construct corresponding measures for the lower and upper bounds of requested working experience (measured in years), as well as their average.

The results are reported in Table 5, where columns (1)-(6) suggest that neither US nor Chinese tariffs had any systematic impact on required working experience. However, we observe in column (7) and (8) that firms exposed to US tariffs significantly decreased the fraction of job ads requiring a college degree. In contrast to this, we obtain positive (but again statistically insignificant) coefficients for the effect of China's retaliation on education background requirements in firms' vacancy postings. The decrease in educational background requirements among US-tariff exposed firms is consistent with the reported decrease in average wage offers and potentially results from a compositional effect as firms scale down on their relatively more exposed skill-intensive goods (see Figure ). ${ }^{32}$

Altogether, our findings suggest that the US-China trade war had a mostly one-sided impact on the labor demand and hiring behavior

\footnotetext{
32 Indeed, we find that the decrease in wage offers due to US tariffs is partially explained by a lower fraction of jobs requiring a college degree. We report the corresponding regression results in Table.
}

ings reflect coincidental correlations. ${ }^{33}$ By assigning tariff exposure randomly to firms in our sample, we expect our earlier findings to disappear if the envisaged mechanism is correctly identified.

Hence, firm $f$ 's "fictional" tariff exposure can be written as:

$\widetilde{\text { Tariff }}_{f, t}^{\text {Type }}=$ Tariff $_{s, t}^{\text {Type }}, \quad$ Type $\in\{$ US, CHN $\}$,

where $s$ indexes a firm that is randomly drawn from our original estimation sample. That is, $f$ adopts the level of exposure we actually for firm $s$, which we draw randomly from our sample. We repeat the above procedure 30 times to obtain a bootstrapped "fictional" sample and carry out our previous analysis once again. The results are reported in Appendix Tables -. None of our previously significant estimates can be reproduced in our placebo estimation, which supports our baseline results and their economic interpretation.

\subsubsection{Control for pre-trends}

Our second robustness check concerns our short sample period. With tariffs entering into force in May and June 2019, and using a one-period lag, we can barely control for pre-trends. This may cast doubts about the existence of a causal relationship between our outcome variables and firms' tariff exposure. In fact, firms' trade structure might be correlated with underlying factors that determine differential trends in labor demand while being unrelated to the trade war. We attempt to address this

\footnotetext{
33 A similar placebo test has been employed by Beverelli et al. (2017) to study the effect of restriction on service trade.
} 
Table 5

Job requirements and exposure to tariffs

\begin{tabular}{|c|c|c|c|c|c|c|c|c|}
\hline \multirow{3}{*}{ Dependent variable } & (1) & (2) & (3) & (4) & (5) & (6) & & (8) \\
\hline & \multicolumn{6}{|c|}{ Previous work experience (in years) } & \multicolumn{2}{|c|}{ College degree } \\
\hline & \multicolumn{2}{|l|}{ Minimum } & \multicolumn{2}{|l|}{ Maximum } & \multicolumn{2}{|l|}{ Average } & \multicolumn{2}{|l|}{ Fraction } \\
\hline \multirow[t]{2}{*}{$\ln \left(1+\operatorname{Tariff}_{f t-1}^{\mathrm{CHN}}\right)$} & 0.006 & 0.022 & -0.024 & -0.007 & -0.009 & 0.008 & 0.027 & 0.023 \\
\hline & $(0.095)$ & $(0.121)$ & $(0.135)$ & $(0.171)$ & $(0.114)$ & $(0.145)$ & $(0.038)$ & $(0.035)$ \\
\hline \multirow{2}{*}{$\ln \left(1+\operatorname{Tariff}_{f t-1}^{\mathrm{US}}\right)$} & -0.067 & 0.018 & -0.067 & 0.040 & -0.067 & 0.029 & $-0.070^{* *}$ & $-0.043^{*}$ \\
\hline & $(0.055)$ & $(0.071)$ & $(0.082)$ & $(0.102)$ & $(0.068)$ & $(0.086)$ & $(0.021)$ & $(0.022)$ \\
\hline Observations & 107,544 & 107,181 & 107,544 & 107,181 & 107,544 & 107,181 & 107,800 & 107,437 \\
\hline R-squared & 0.745 & 0.748 & 0.744 & 0.748 & 0.745 & 0.749 & 0.712 & 0.716 \\
\hline City Control & $\mathrm{Y}$ & & $\mathrm{Y}$ & & $\mathrm{Y}$ & & $\mathrm{Y}$ & \\
\hline Month FE & $\mathrm{Y}$ & & $\mathrm{Y}$ & & $\mathrm{Y}$ & & $\mathrm{Y}$ & \\
\hline Firm FE & $\mathrm{Y}$ & Y & $\mathrm{Y}$ & $\mathrm{Y}$ & Y & $\mathrm{Y}$ & $\mathrm{Y}$ & $\mathrm{Y}$ \\
\hline City-Month FE & & Y & & Y & & $\mathrm{Y}$ & & $\mathrm{Y}$ \\
\hline Sector-Month FE & & $\mathrm{Y}$ & & $\mathrm{Y}$ & & $\mathrm{Y}$ & & $\mathrm{Y}$ \\
\hline
\end{tabular}

Notes: Regressions use firm online job vacancy data from May through November 2019. Dependent variables denote number of years in columns (1)-(6) and fractions in columns (7)-(8); coefficients report estimated semielasticities. Time-varying city-level controls include total number of firms and vacancies observed. Standard errors are reported in parentheses and adjusted for clustering at the city and month level. Statistical significance: *** $\mathrm{p}<0.01,{ }^{* *} \mathrm{p}<0.05,{ }^{*} \mathrm{p}<0.1$.

concern by drawing on information from the Annual Survey of Industrial Production (ASIP), which allows us to observe actual employment and average wages paid for a subset of our firms in the years 2012-2013; long before the trade war. ${ }^{34}$ Inference relies on a falsification test in which we estimate the observed firm-level change in (log) employment and (log) average wage payments between 2012 and 2013. A statistically significant coefficients for our measures of tariff exposure would suggest a potentially underlying long-term trend in our data and challenge our identification.

Table presents the results for realized employment in columns (1)(4) and for average realized wages in columns (5)-(8), using different combinations of fixed effects and controls. Without any fixed effects or firm-level controls, we find systematically higher employment growth among US-tariff exposed firms and slower wage increases. Estimated coefficients are corrected downwards and lose statistical significance as soon as we include industry fixed effects, city fixed effects or firm-level control variables (i.e. total sales). Exposure to Chinese retaliation tariffs reveals statistically insignificant results throughout and with opposite signs. Compared to our main results, historical employment among exposed firms appears to have followed a different trend, which lends some confidence to our identification strategy. The results are somewhat less conclusive for historical wage growth, where coefficients reveal the same sign but statistical significance is considerably weaker.

\subsubsection{Timing of the effects}

Instead of considering historical employment and wage growth for a subset of firms, we might infer validity also by looking at the timing of the estimated effects. The most intuitive assumption would be to expect adjustments to occur immediately or at least soon after newly imposed tariffs apply. Later adjustments should be weaker. However, if our estimated coefficients capture an underlying pre-trend, we should observe fairly similar effects at different instances in our sample.

In Table, we include deeper lags of tariff exposure into our regression for the number of job vacancies posted by firms. Estimated responses to China's retaliatory tariffs remain fairly fragile and inconsistent across specifications, like in our main findings. Additional US tariffs appear to have mainly immediate effects and weaker (and less consistent) effects in later periods. Tables - further support this finding, suggesting that deeper lags of tariffs alone are statistically insignificant for most of our

\footnotetext{
34 The ASIP is conducted by the National Bureau of Statistics of China. The survey includes manufacturing sector firms whose revenue is more than five million RMB each year. We are able to match 4,669 firms based on their reported company name and location.
}

outcome variables, and considerably smaller and less significant for the number of vacancies.

\subsubsection{Alternative control groups}

We scrutinize identification further by considering alternative control groups. Our original sample pools different groups of firms, including those that did not sell to or source from the US at all (henceforth, Group 1, being unexposed by definition) and those that traded with the US, but not in goods targeted by China III/IV tariffs (Group 2). The former counts 7,676 firms in our estimation sample and should facilitate better identification than the latter, which counts only 1,213 firms. Group 2 can be viewed as being exposed to a higher tariff risk, and hence more similar to the treatment group, given its trade linkages with the US, potential treatment in earlier rounds (China I and II) and the surrounding trade policy uncertainty (e.g. Benguria et al., 2020). ${ }^{35}$

When we re-estimate our main specifications on vacancy postings considering the respective control groups separately, we find that reductions in the number of job ads are quantitatively and statistically more pronounced relative to Group 1. In fact, as shown in columns (3)(4) of Table, the estimated semi-elasticity of new vacancy postings with respect to US tariff increases is almost twice as high relative to Group 1 than for Group 2. Also responses to retaliation tariffs appear to be more pronounced relative to the non-exposed set of firms that never traded with the US in the base-year 2016. The fact that results remain statistically significant even when we keep control Group 1 out of our sample suggests that identification operates also via the product-mix of firms' imports and exports, which results in differential degrees of exposure to tariffs.

We conclude from this subsection that firm-level adjustments in the number of vacancy postings (i.e. labor demand) can be interpreted as causally related to tariff increases experienced during the trade war. Adjustments in other dimensions have been generally more fragile, making rigorous causal inference more difficult.

\subsection{Firm heterogeneity}

So far, our results revealed the estimated average tariff effects and we have not paid much attention to potentially heterogeneous responses

\footnotetext{
35 The treatment group comprises 12,600 firms in our sample, so that the overall population amounts to 21,489 firms. This number results from the fact that some firms have only one (or few) observations in total during the sample period, so that the inclusion of fixed effects results in perfectly collinearity and removal from the sample.
} 
across firms. To explore this, we consider two main dimensions of firm heterogeneity in this subsection, distinguishing their size (as revealed from the aggregated trade volume in our base-year 2016) and their ownership (as revealed from the firm-level information provided via the online job portal 51job.com). We also consider potentially heterogeneous responses between firms with different trade baskets in terms of product range and characteristics.

\subsubsection{Firm size}

Based on their observed trade volumes in 2016 (i.e., exports plus imports), we divide firms into three equally-sized groups: small, medium and large. For each of these subsamples, we re-run our main specifications and report the obtained point estimates with corresponding $95 \%$ confidence intervals graphically. ${ }^{36}$

Figure presents estimates for labor demand, as measured by their total number of job vacancy postings. Responses to higher US tariffs are displayed on the left, while adjustments to Chinese tariffs are shown on the right. Panel (a) reports the semi-elasticities obtained from our linear panel specification, while Panel (b) reports estimated elasticities obtained from the Poisson model. Figure reports findings for changes in offered wages among firms' job ads, while Figures and focus on the different forms of non-wage compensation and advertised job-prerequisites, respectively.

We find that large firms tend to be the least responsive to any kind of tariff and in terms of most outcome variables. In some cases, large confidence intervals suggest heterogeneity even within this group, but point estimates for the number of vacancy postings or advertised wage offers are typically closer to zero than for other firms. A tendency towards increasing number of job postings offering bonus payments and employee subsidies can be observed for these firms, as well as a modest increase in educational requirements when facing US tariffs. This contrasts with the findings for other firms and also with average effect found for the pooled sample above.

Concerning small firms, we find this group to be the most diverse, given the large confidence intervals. While point estimates indicate substantial downward adjustments in job postings, wage offers, subsidy offers and job pre-requisites (following US tariff increases), they rarely pass the $5 \%$ significance threshold. Adjustments are typically more modest and less precisely estimated in the case of Chinese retaliatory tariffs. Despite their within-group heterogeneity, however, they seem to contribute to the robust results reported for adjustments to US tariffs in terms of labor demand, wage offers and educational background requirements.

Medium-sized firms constitute the group with the clearest results overall. They appear to scale down, offer lower wages, and request less educational background (and to some extent working experience) when facing additional US tariffs. Non-wage compensation tends to increase most significantly in terms of subsidies and modestly in terms of offering bonus payments (like most other firms). Interestingly, when affected by Chinese retaliatory tariffs, these firms appear to increase efforts to attract more educated and experienced workers, which reveals from adjustments in announced job-prerequisites and from a marginal increase in offered wages and bonus payments. Such a pattern cannot be observed in other groups and might indicate that medium-sized firms seek to produce previously imported inputs themselves.

\subsubsection{Firm ownership}

Different ownership structures might result in diverse adjustment strategies to tariffs, as firms rely on different decision-making procedures, resources, and networks. For example, while state-owned firms might be theoretically more protected from bankruptcy, foreign owned

\footnotetext{
${ }^{36}$ In our sample periods (i.e., May to November of 2019), the average exposure to US tariffs for small-, medium-, and large-size firms are 0.03, 0.09 and 0.13, respectively; the average exposure to China's tariffs for small-, medium-, and large-size firms are 0.04, 0.06 and 0.10, respectively.
}

firms might be able to rely on an international network that allows them to re-route trade flows and cushion the effect of bilateral trade barriers (Flaaen et al., 2020). Domestic private firms would be most directly exposed to market forces and less resilient to short-term policy shocks. Figure presents estimates for the number of job-ads, separately for state-owned enterprises, foreign owned firms and private domestic enterprises. ${ }^{37}$ Figure displays corresponding results for average wage offers, while Figures and show findings for offered non-wage compensation and job-requirements.

Considering responses to US tariff increases first, our estimated average effects appear to be driven mainly (and sometimes exclusively) by the privately-owned domestic enterprises. They indicate highly significant reductions in the number job postings, announced wage offers and educational requirements. Chinese SOEs also report lower numbers of job postings, but deviate in their responses regarding wage offers and requested educational background. The job advertising behavior of foreign owned enterprises appears to be virtually unaffected by the US tariffs, which might suggests that these firms have ways to circumvent tariffs.

Turning to China's retaliatory tariffs, besides posting fewer vacancies, privately-owned domestic firms appear to be relatively nonresponsive, while China's SOEs show some (but generally imprecisely estimated) adjustments in hiring activity, average compensation offers and job requirements. Foreign-owned firms stand out by significantly lowering their number of job vacancy postings, while increasing wage and bonus payment offers. While strong conclusions from these patterns should be treated with caution, fewer and better-paid job offers by foreign-owned firms could suggest that interrupted supply chains resulted in downscaling of their production and a shift towards more strategic and management-oriented activities in the short term. Chinese firms in turn might be more efficient in switching quickly to alternative suppliers so that additional tariffs on US imports result in fewer observable adjustments, although they also show signs of scaling down by posting fewer job ads.

\subsubsection{Further dimensions}

Next to firm heterogeneity in terms of size and ownership, also the product mix of their imports and exports might determine tariff effects on labor demand. For example, firms that sell mainly homogeneous (i.e. highly standardized) products face stiffer competition and might be hit harder by a tariff than firms that sell differentiated (or even customized) goods. The latter translates into a relatively lower elasticity of substitution and a smaller tariff effect. Conversely, firms that source mainly homogeneous goods might find it easier to substitute suppliers than those who import differentiated products. Our results in Panel A of Table seem to support this reasoning when we interact tariff effects with the fraction of homogeneous goods in firms' respective trade basket to estimate adjustments in the number of vacancy postings and average wage offers. ${ }^{38}$ Other attributes of job vacancies do not reveal any statistically different effects along this dimension.

We also find some differential adjustments for firms trading a relatively narrow range of products, which might make it harder to switch to alternative revenue sources. As we show in Panel B of Table, when facing additional US tariffs, such firms offer lower wages and more bonus payments, while requiring lower educational background and more work-

\footnotetext{
37 Information on firm ownership is provided by the online job-ad platform. State-owned firms includes public institution, state-owned enterprise and government agencies. Foreign-owned firms are enterprises owned by foreign nationals, and the rest are private firms. In the regression sample state-owned and foreign-owned firms account for $5.80 \%$ and $28.6 \%$ of the total, respectively.

38 We use the conventional classification by Rauch (1999) to determine firms' homogeneous product share in exports and imports in the base year 2016.
} 
ing experience than other firms. ${ }^{39}$ Narrow-range importers reveal significantly differential adjustments only for the number of vacancy postings, where they indicate increased hiring activity. This could suggest that relatively "specialized" importers seek to switch towards in-house production, although announced job prerequisites and compensation does not indicate significantly different responses.

\subsection{Discussion}

Our results indicate a fairly consistent negative impact of the trade war on revealed hiring intentions and wage offers by Chinese firms. While providing novel and complementary insights to existing research, we remain aware of some data limitations that could potentially impact our estimates.

The first limitation relates to the existence of so-called "phantom vacancies" in online job portals (Cheron and Decreuse, 2017; Kureková et al., 2015), which we mentioned already in Section 2. As long as such de facto inactive vacancies do not systematically appear among the either more or less exposed firms in our sample, we obtain a conventional measurement error in our dependent variable which leads to imprecision in our estimates. However, if "phantom vacancies" concentrate among the more exposed firms, the adverse tariff-effects would be underestimated. This could happen, for example, if exposed firms keep their obsolete job ads to buffer competition and uncertainty during the trade tensions. While the resulting bias and imprecision would be prevalent in almost all our specifications, our flow measure of the number of firm-level job postings, where we only consider job ad's first-ever appearance, should be immune to this issue.

Other limitations concern the potential existence of pre-trends in our variables that could impact our estimates. Although we attempt to address this issue in our robustness checks, we cannot fully rule out this possibility. Similarly, our measures of tariff exposure could be correlated with dependent variables via mechanisms that are independent of a firm's trade composition. For instance, if the Chinese government implements policies to mitigate risks from trade tensions for certain firms, we might underestimate the actual impact of the tariff. Moreover, given that we observe a fairly late stage of the trade war, we expect - as mentioned earlier in the paper - that the full range and scope of firm-level adjustments might not be revealed from our data. Given these limitations, as well as potentially further indirect effects of the trade war, we expect to provide rather conservative estimates of its impact on firms' labor demand.

\section{Concluding remarks}

In this paper, we present new evidence on the labor market effects of bilateral tariffs which were reciprocally applied in a recent period of increased political tensions between the US and China. We exploit information from a newly compiled data set of vacancy postings in China, which enables us to trace firms' hiring intentions and advertised job characteristics over time. Our findings suggest that the trade war exerted predominantly destructive effects, which we observe in terms of overall job-posting activity, but also in the announced wage compensation.

A novel feature of our study is the use of vacancy postings which we extracted from a popular Chinese online job portal, 51job.com. A key advantage of the data, next to its timely availability, is that it provides detailed insights into the demand side of the labor market. Although such data does not allow us to observe firms' actual employment, it enables us to observe when and how often firms post a new vacancy and what they are looking for exactly. Such information reveals insights on firms'

\footnotetext{
39 We define those firms based on the number of goods they exported and imported in 2016 and consider the bottom third as "small-scope" enterprises, using a binary indicator variable as an interaction term.
}

short-term future-oriented decision making. We further document that our data is highly representative of the general scale of economic activity across Chinese prefectural cities. Nevertheless, the general tendency of online job vacancy data to be skewed towards relatively higher-paid white-collar jobs implies that also our findings capture only a part of the labor-demand response to the trade war. Blue-collar jobs might reveal similar or perhaps even stronger responses which we do not capture in our paper.

For our analysis, we exploit information from a subset of international trading firms, which we identify via matching information reported in China Customs Statistics. Our measure of tariff exposure is therefore constrained to the directly exposed firms, although we could expect that major adjustments to the trade policy shock might propagate via firms' local supply networks (Dhyne et al., 2021). While our data does not allow us to trace such networks, identifying such firm-to-firm trade linkages within China would likely increase the overall scope of exposure to the trade war and allow us to measure and evaluate it more precisely and in a larger sample. We, therefore, interpret our findings as a lower bound whenever we report aggregates, such as the estimated total reduction in the number of job ads.

Future research, combining the information from online job boards with other firm-level data sets, might reveal further insights into firmlevel responses to tariffs and other shocks, thereby contributing to our understanding of their different transmission channels, direct and indirect effects, which is necessary to design effective policies.

\section{Supplementary material}

Supplementary material associated with this article can be found, in the online version, at 10.1016/j.labeco.2021.102021

\section{References}

Albrecht, J., Cai, X., Gautier, P., Vroman, S., 2020. Multiple applications, competing mechanisms, and market power. Journal of Economic Theory 190, 105121

Amiti, M., Kong, S.H., Weinstein, D., 2020. The Effect of the U.S.-China Trade War on U.S. Investment. NBER Working Papers. National Bureau of Economic Research, Inc. https://ideas.repec.org/p/nbr/nberwo/27114.html

Amiti, M., Redding, S. J., Weinstein, D., 2019. The Impact of the 2018 Trade War on US Prices and Welfare. NBER Working Paper \#25672.

Atkin, D., 2016. Endogenous skill acquisition and export manufacturing in mexico. American Economic Review 106 (8), 2046-2085.

Azar, J.A., Marinescu, I., Steinbaum, M.I., Taska, B., 2018. Concentration in US labor markets: Evidence from online vacancy data. Technical Report. National Bureau of Economic Research.

Benguria, F., Choi, J., Swenson, D.L., Xu, M., 2020. Anxiety or Pain? The Impact of Tariffs and Uncertainty on Chinese Firms in the Trade War. Working Paper. National Bureau of Economic Research.

Bernard, A.B., Fort, T.C., Smeets, V., Warzynski, F., 2020. Heterogeneous Globalization: Offshoring and Reorganization. NBER Working Papers. National Bureau of Economic Research, Inc. https://ideas.repec.org/p/nbr/nberwo/26854.html

Beverelli, C., Fiorini, M., Hoekman, B., 2017. Services trade policy and manufacturing productivity: The role of institutions. Journal of International Economics 104, 166-182.

Blanchard, E.J., Olney, W.W., 2017. Globalization and human capital investment: Export composition drives educational attainment. Journal of International Economics 106, $165-183$.

Bloom, N., Bond, S., Van Reenen, J., 2007. Uncertainty and Investment Dynamics. The Review of Economic Studies 74 (2), 391-415.

Bown, C., Kolb, M., 2019. Trump's Trade War Timeline: An Up-To-Date Guide. Peterson Institute for International Economics May.

Brown, J., Matsa, D.A., 2016. Boarding a sinking ship? an investigation of job applications to distressed firms. The Journal of Finance 71 (2), 507-550.

Cai, J., Stoyanov, A., 2016. Population aging and comparative advantage. Journal of International Economics 102, 1-21.

Cai, X., Gautier, P.A., Wolthoff, R.P., 2017. Search frictions, competing mechanisms and optimal market segmentation. Journal of Economic theory 169, 453-473.

Caliendo, L., Mion, G., Opromolla, L.D., Rossi-Hansberg, E., 2020. Productivity and organization in portuguese firms. Journal of Political Economy 128 (11), 4211-4257.

Cavallo, A., Gopinath, G., Neiman, B., Tang, J., 2019. Tariff Passthrough at the Border and at the Store: Evidence from US Trade Policy. NBER Working Papers. National Bureau of Economic Research, Inc. https://ideas.repec.org/p/nbr/nberwo/26396.html

Cheron, A., Decreuse, B., 2017. Matching with phantoms. The Review of Economic Studies 84 (3), 1041-1070.

Davis, S.J., Faberman, R.J., Haltiwanger, J., 2012. Labor market flows in the cross section and over time. Journal of Monetary Economics 59 (1), 1-18.

Davis, S.J., Faberman, R.J., Haltiwanger, J.C., 2013. The establishment-level behavior of vacancies and hiring. The Quarterly Journal of Economics 128 (2), 581-622. 
Deming, D., Kahn, L.B., 2018. Skill requirements across firms and labor markets: Evidence from job postings for professionals. Journal of Labor Economics 36 (S1), S337-S369.

Dhyne, E., Kikkawa, A.K., Mogstad, M., Tintelnot, F., 2021. Trade and Domestic Production Networks. The Review of Economic Studies 88 (2), 643-668.

Ebrahimy, E., Shimer, R., 2010. Stock-flow matching. Journal of Economic Theory 145 (4), 1325-1353.

Egger, P., Zhu, J., 2019. The U.S.-Chinese Trade War: An Event Study of Stock-Market Responses. CEPR Discussion Papers. C.E.P.R. Discussion Papers. https://ideas.repec.org/p/cpr/ceprdp/14164.html

Faberman, R.J., Kudlyak, M., 2016. What does online job search tell us about the labor market? Economic Perspectives, Federal Reserve Bank of Chicago 1 (1), 1-15. https://econpapers.repec.org/article/fipfedhep/00018.htm

Fajgelbaum, P.D., Goldberg, P.K., Kennedy, P.J., Khandelwal, A.K., 2020. The Return to Protectionism. The Quarterly Journal of Economics 135 (1), 1-55.

Flaaen, A., Hortaçsu, A., Tintelnot, F., 2020. The production relocation and price effects of US trade policy: The case of washing machines. American Economic Review 110 (7), 2103-2127. doi:10.1257/aer.20190611.

Flaaen, A., Pierce, J., 2020. Disentangling the Effects of the 2018-2019 Tariffs on a Globally Connected U.S. Manufacturing Sector. F.R.E.I.T. working paper, no 1727, https://www.freit.org/WorkingPapers/Papers/TradePolicyMultilateral/FREIT1727.pdf.

Ghosal, V., Ye, Y., 2015. Uncertainty and the employment dynamics of small and large businesses. Small Business Economics 44 (3), 529-558.

Goswami, S., 2020. Employment Consequences of U.S. Trade Wars. https://sanjanagoswami.github.io/files/sgoswami_jmp.pdf, University of California, Irvine.

Gregg, P., Petrongolo, B., 2005. Stock-flow matching and the performance of the labor market. European Economic Review 49 (8), 1987-2011.

Handley, K., 2014. Exporting under trade policy uncertainty: Theory and evidence. Journal of International Economics 94 (1), 50-66.

Handley, K., Kamal, F., Monarch, R., 2020. Rising Import Tariffs, Falling Export Growth: When Modern Supply Chains Meet Old-Style Protectionism. NBER Working Papers. National Bureau of Economic Research, Inc.

Handley, K., Limão, N., 2015. Trade and Investment under Policy Uncertainty: Theory and Firm Evidence. American Economic Journal: Economic Policy 7 (4), 189-222.

Handley, K., Limão, N., Ludema, R.D., Yu, Z., 2020. Firm Input Choice Under Trade Policy Uncertainty. Working Paper. National Bureau of Economic Research doi:10.3386/w27910.

Hummels, D., Munch, J.R., Xiang, C., 2018. Offshoring and Labor Markets. Journal of Economic Literature 56 (3), 981-1028.

Javorcik, B., Kett, B., O'Kane, L., 2019. The Brexit Vote and Labour Demand: Evidence from Online Job Postings. Economics Series Working Papers. University of Oxford, Department of Economics. https://ideas.repec.org/p/oxf/wpaper/878.html

Kahn, L.B., Hershbein, B., 2018. Do recessions accelerate routine-biased technological change? American Economic Review 108 (7), 1737-1772.

Kuhn, P., Shen, K., 2013. Gender Discrimination in Job Ads: Evidence from China. The Quarterly Journal of Economics 287-336. doi:10.1093/qje/qjs046.Advance.
Kuhn, P., Skuterud, M., 2004. Internet job search and unemployment durations. American Economic Review 94 (1), 218-232.

Kureková, L.M., Beblavỳ, M., Thum-Thysen, A., 2015. Using online vacancies and web surveys to analyse the labour market: a methodological inquiry. IZA Journal of Labor Economics 4 (1), 1-20.

Li, M., 2018. CARD Trade War Tariffs Database.

Liu, T., Makridis, C., Ouimet, P., Simintzi, E., 2019. The distribution of non-wage benefits: Maternity benefits and gender diversity. Available at SSRN 3088067.

Luft, J., 1994. Bonus and penalty incentives contract choice by employees. Journal of Accounting and Economics 18 (2), 181-206.

Mamertino, M., Sinclair, T.M., 2016. Online job search and migration intentions across EU member states. Institute for International Economic Policy Working Paper Series.

Marinescu, I., 2017. The general equilibrium impacts of unemployment insurance: Evidence from a large online job board. Journal of Public Economics 150, 14-29.

Marinescu, I., Rathelot, R., 2018. Mismatch unemployment and the geography of job search. American Economic Journal: Macroeconomics 10 (3), 42-70.

Mau, K., Xu, M., 2019. Economic growth and complexity across chinese regions: the role of cost-saving production diffusion.

Meinen, P., Schulte, P., Cigna, S., Steinhoff, N., 2019. The Impact of US Tariffs Against China on US Imports: Evidence for Trade Diversion? Deutsche Bundesbank Discussion Paper. Deutsche Bundesbank.

Melitz, M.J., 2003. The Impact of Trade on Intra-Industry Reallocations and Aggregate Industry Productivity. Econometrica 71 (6), 1695-1725.

Melitz, M.J., Ottaviano, G.I.P., 2008. Market Size, Trade, and Productivity. Review of Economic Studies 75 (1), 295-316.

Melitz, M.J., Trefler, D., 2012. Gains from Trade When Firms Matter. Journal of Economic Perspectives 26 (2), 91-118.

Rauch, J.E., 1999. Networks versus markets in international trade. Journal of International Economics 48 (1), 7-35.

Albrecht, J., Decreuse, B., Vroman, S., 2017. Directed search with phantom vacancies.

Stein, L. C. D., Stone, E., 2013. The Effect of Uncertainty on Investment, Hiring, and R\&D: Causal Evidence from Equity Options. https://doi.org/10.2139/ssrn.1649108, Available at SSRN.

Turrell, A., Speigner, B., Djumalieva, J., Copple, D., Thurgood, J., 2019. Transforming Naturally Occurring Text Data Into Economic Statistics: The Case of Online Job Vacancy Postings. National Bureau of Economic Research doi:10.3386/w25837.

Waugh, M.E., 2019. The Consumption Response to Trade Shocks: Evidence from the US-China Trade War. Working Paper. National Bureau of Economic Research.

Woodbury, S.A., 1983. Substitution between wage and nonwage benefits. The American Economic Review 73 (1), 166-182.

Wooldridge, J.M., 2010. Econometric analysis of cross section and panel data. MIT press.

WSJ, 2020. China Trade War Didn't Boost U.S. Manufacturing Might. Article. The Wall Street Journal. https://www.wsj.com/ articles/china-trade-war-didnt-boost-u-s-manufacturing-might-11603618203 